\title{
PENERAPAN CRITICAL REVIEW ARTIKEL PEMBELAJARAN IPA UNTUK MENINGKATKAN KEMAMPUAN MAHASISWA DALAM MENYUSUN PROPOSAL SKRIPSI
}

\author{
Parmin
}

\begin{abstract}
The aims of this research is to improve students' ability in developing a proposal thesis by applying critical review of scientific articles come from journals. The research is designed by class action research. The results showed $63 \%$ of students thesis proposals on Research Methodology course scored above 80 . Based on the results obtained it can be concluded that the application has been critical review or critical study of scientific articles can enhance students' ability in preparing research proposals.
\end{abstract}

Keywords: critical review, scientific article, journal and thesis proposal 


\section{PENDAHULUAN}

Perbaikan kualitas pembelajaran yang didasarkan dari kegiatan refleksi penyelenggaraan suatu mata kuliah secara substantif terus dilakukan melalui program perbaikan proses, diantaranya penerapan strategi aplikatif agar mahasiswa memiliki pengetahuan sekaligus pengalaman setelah mempelajari suatu materi pembelajaran. Sumber belajar yang aplikatif diantaranya telah teruji melalui proses penelitian yang antara lain dipublikasikan melalui jurnal. Berbagai artikel jurnal dapat dikaji dan dipelajari untuk mata kuliah yang sesuai agar mendukung pencapaian kompetensi mahasiswa.

Penyelenggaraan mata kuliah Metodologi Penelitian di Prodi Pendidikan IPA S1 dirancang khusus agar mahasiswa pada semester $\mathrm{V}$ memiliki pengetahuan dan pengalaman menyusun proposal skripsi. Dalam pelaksanaannya mahasiswa mempelajari berbagai metode penelitian pendidikan, teknik melakukan observasi pembelajaran untuk mengidentifikasi permasalahan belajar IPA di sekolah sehingga diharapkan mampu mengembangkan ide dan menjadi tema skripsi yang berkaitan dengan permasalahan pembelajaran IPA terpadu di sekolah.

Berdasarkan refleksi yang telah dilakukan dosen pengampu pada penugasan penyusunan proposal penelitian. Telah teridentifikasi beberapa permasalahan yang menunjukkan bahwa kemampuan mahasiswa dalam menyusun proposal penelitian belum sesuai harapan, berbagai permasalahan yang ditemukan yaitu; judul skripsi sebagian besar bukan hasil identifikasi permasalahan pembelajaran di sekolah melainkan membaca skripsi pendahulu, kajian pustaka yang digunakan tidak faktual karena tidak bersumber dari rujukan yang terbaru, dan minim rujukan yang bersumber dari jurnal hasil penelitian. Data menunjukkan dari 38 mahasiswa dalam satu rombongan belajar yang mendapatkan nilai proposal penelitian $\geq 80$ kurang dari $25 \%$, artinya proposal yang dibuat sebagian besar tidak layak dilanjutkan untuk skripsi sehingga secara umum tujuan mata kuliah agar mahasiswa dapat menyusun proposal penelitian yang mendapat penilaian layak untuk proposal skripsi belum tercapai.

Mahasiswa dalam penugasan membuat proposal penelitian, 
ide dan gagasan tidak dapat berkembang karena sebagian teridentifikasi mengcopi proposal skripsi milik orang lain dalam bentuk skripsi. Pengenalan berbagai metode penelitian dalam proses pembelajaran dan observasi ke sekolah untuk mengidentifikasi permasalahan pembelajaran IPA, ternyata belum berdampak positif terhadap kemampuan mahasiswa dalam menyusun proposal yang layak dilanjutkan ke pembimbingan skripsi. Permasalahan utama terdapat pada kemampuan mahasiswa dalam melakukan kajian berbagai aspek yang berkaitan penelitian, seperti kajian terhadap kurikulum, strategi pembelajaran, artikel dan tulisan ilmiah kurang sehingga keberanian untuk menyusun rancangan penelitian secara mandiri sebagian besar mahasiswa tidak muncul. Sesungguhnya kemampuan mahasiswa dalam melakukan kajian kritis dari artikel hasil penelitian, dapat digunakan untuk membuat rancangan melalui pemilihan materi atau bahan ajar, bentuk tindakan dan kajian teori yang mendukung. Daya dukung ketersediaan jurnal yang mempublikasikan hasil penelitian pembelajaran IPA di sekolah juga cukup banyak.

Suatu kegiatan membaca, menelaah, menganalisis bacaan/artikel untuk memperoleh ide-ide, penjelasan, data-data pendukung yang mendukung pokok pikiran utama, serta memberikan komentar terhadap isi bacaan secara keseluruhan dari sudut pandang kepentingan pengkaji. Kemampuan melakukan kajian kritis sangat diperlukan oleh guru, kepala sekolah, dan pengawas sekolah untuk melakukan kajian kritis terhadap berbagai aspek yang berkaitan dengan tugas dan tanggung jawabnya, seperti kajian kritis terhadap kurikulum, strategi pembelajaran, artikel dan tulisan ilmiah lainnya. Kemampuan melakukan kajian kritis, dapat digunakan untuk membuat laporan dan memilih materi atau bahan ajar, menilai dan memberi masukan terhadap tulisan memperoleh informasi sesuai dengan apa yang ditulis.

Penelitian bertujuan untuk meningkatkan kemampuan mahasiswa dalam menyusun proposal skripsi melalui penerapan critical review artikel jurnal hasil penelitian pembelajaran IPA di sekolah. Mahasiswa dalam pembelajaran akan diarahkan untuk menghasilkan produk dalam bentuk proposal penelitian yang layak dilanjutkan 
ke pembimbingan skripsi.

Teori kritik memiliki dua pengertian yang berbeda, yaitu teori kritik sosial dan teori kritik literatur. Penekanan kedua teori berbeda karena pada kritik literatur lebih pada pemahaman dan analisis terhadap sumber belajar dalam rangka menemukan kebaikan dan kelamahan, tanpa bermaksud lebih jauh untuk melakukan perubahan terhadap literatur yang dikaji. Dalam rangka pengembangan kompetensi guru maka memahami makna kajian kritis dipandang sangat diperlukan. Kemampuan mengkaji literatur meliputi; kemampuan berpikir kritis (critical thinking), membaca kritis (critical reading), dan melakukan kajian kritis (critical review) (Heriawan, 2009).

Kajian kritis merupakan suatu kegiatan membaca, menelaah, menganalisis suatu bacaan/artikel untuk memperoleh ide-ide, penjelasan, data-data pendukung yang mendukung pokok pikiran utama, serta memberikan komentar terhadap isi bacaan secara keseluruhan dari sudut pandang kepentingan pengkaji. Kemampuan melakukan kajian kritis sangat diperlukan oleh seorang guru terhadap berbagai aspek yang berkaitan dengan tugas dan tanggung jawabnya, seperti kajian kritis terhadap kurikulum, strategi pembelajaran, artikel dan tulisan ilmiah lainnya. Kemampuan melakukan kajian kritis, dapat digunakan untuk membuat laporan dan memilih materi atau bahan ajar.

Tujuan melakukan kajian kritis terhadap suatu sumber belajar yaitu menilai dan memberi masukan terhadap tulisan dan memperoleh informasi sesuai dengan apa yang ditulis. Sementara itu, terdapat tiga prinsip kajian kritis meliputi: a) kajian ilmiah/objektif berupa; 1) menyajikan data, fakta dan opini secara objektif dan logis, 2) pernyataan dalam kalimat tulus, benar, sesuai aturan dan norma yang berlaku serta sesuai dengan kaidah bahasa yang berlaku, dan 3) tidak memuat pandangan-pandangan tanpa dukungan fakta, tidak emosional atau menonjolkan emosi; b) sikap ilmiah/prediktif, ada beberapa sikap kritis dalam bentuk sikap ilmiah yang meliputi 1) sikap ingin tahu, kritis, terbuka, dan objektif, 2) menghargai karya orang lain, 3) berani mempertahankan kebenaran, dan 4) mempunyai pandangan luas dan jauh ke depan; dan c) sistematis 
menuntut kajian dilakukan secara berurutan dan terpadu sehingga satu aspek dengan aspek lainnya membentuk suatu keseluruhan yang tertata rapi.

Struktur kajian kritis meliputi; a) pendahuluan yang berisi menerangkan judul apa, siapa pengarang, penjelasan umum mengenai topik artikel/buku, tujuan penulisan artikel/buku, ringkasan mengenai apa yang disimpulkan dari artikel/buku, argumentasi serta alasannya, serta diakhiri dengan pernyataan umum mengenai penilaian terhadap artikel/buku. Umumnya bagian pendahuluan menghabiskan maksimal satu halaman untuk kajian terhadap artikel dan maksimal tiga halaman untuk kajian terhadap buku; b) rangkuman yang berisikan point-point pokok artikel/buku beserta contoh-contohnya.

Selain itu, kajian kritis dapat juga memuat penjelasan mengenai maksud penulis artikel/buku dan bagaimana artikel/buku disusun/diorganisasi. Panjang bagian rangkuman artikel/buku sekitar sepertiga dari tulisan kajian kritis; c) kritik yang berisi pemaparan yang harus seimbang antara diskusi dengan penilaian terhadap kelebihan, kelemahan, dan hal-hal krusial (penting) dari artikel/ buku. Dasar pertimbangan pada kriteria yang khusus, dan sertakan literatur lain untuk mendukung penilaian; d) simpulan yang berisi beberapa paragraf saja. Paparkan kembali secara umum keseluruhan penilaian terhadap artikel/buku dan nyatakan secara umum rekomendasi yang diusulkan. Jika perlu, beberapa penjelasan tentang penilaian kita dapat ditulis sehingga tampak bahwa kritik kita cukup adil dan beralasan; dan e) referensi jika menggunakan sumber kepustakaan lain dalam kajian tersebut, maka harus dinyatakan sebagai daftar pustaka pada bagian ini secara jelas.

Untuk meningkatkan kompetensi merencanakan penelitian dalam bidang IPA bisa dilakukan dengan cara membiasakan mahasiswa bekerja ilmiah, karena dengan kebiasaan tersebut dapat menumbuhkan kebiasaan berpikir dan berindak yang merefleksikan penguasaan pengetahuan, keterampilan dan sikap ilmiah mahasiswa (Sopiah, 2009).

Jurnal penelitian kependidikan berisikan kumpulan artikel tentang hasil-hasil penelitian di berbagai jenjang pendidikan. Artikel 
yang dimuat di jurnal telah melalui mekanisme seleksi administrasi dan akademik dari editor. Oleh karena itu, berbagai artikel yang dimuat di jurnal dapat dijadikan referensi untuk melakukan penelitian lanjutan atau sebagai sumber belajar.

Untuk mengkomunikasikan hasil penelitian, diperlukan media yang dapat diakses dengan mudah seperti jurnal ilmiah yang dipublikasikan secara online. Dalam jurnal terdapat aplikasi praktis termasuk analisis desain, studi kasus, analisa kembali, dan validasi laboratorium dan lapangan; proses konstruksi dan pendidikan yang sangat diperlukan sebagai pengayaan pembelajaran.

Jumlah jurnal yang berisi artikel penelitian pendidikan IPA saat ini telah tersedia dalam jumlah banyak baik pada jurnal maupun e-jurnal. Mahasiswa dapat menggunakan artikel sebagai bahan belajar untuk dilakukan kajian secara sistematis dan jelas. Kegiatan kajian kritis dengan sistematika yang telah dijabarkan pada kajian teori dapat membantu mahasiswa dalam menyajikan hasil kajian kritis dari artikel jurnal penelitian pendidikan IPA di sekolah.

Mata kuliah metodologi penelitian pendidikan IPA di Prodi Pendidikan IPA S1, berkode PIP 207, bobot SKS 3. Mata kuliah ini menyajikan materi terkait dengan pengertian metode penelitian, jenis dan pendekatan penelitian pendidikan, cara mengadakan penelitian, memilih masalah, studi pendahuluan, merumuskan masalah, anggapan dasar, dan hipotesis, menentukan dan menyusun instrumen (lengkap dengan rumus penentuan sampel tolok ukur instrumen), analisis data yang dilengkapi dengan uji normalitas dan homogenitas sampel, menarik kesimpulan, dan teknik penulisan proposal penelitian pendidikan.

Setelah menyelesaikan mata kuliah ini mahasiswa diharapkan mampu memahami; $\quad$ (a) filsafat, hakekat, dan metode ilmiah; (b) cara mengadakan penelitian; (c) memilih masalah; $\quad$ (d) studi pendahuluan; (e) merumuskan masalah, anggapan dasar, dan hipotesis; (f) populasi, sampel, dan cara pengambilan sampel, (g) menentukan dan menyusun instrumen serta analisisnya; (h) cara analisis data; serta (i) membuat dan menyusun proposal skripsi pendidikan IPA terpadu di sekolah.

Pembelajaran metode penelitian menggunakan berbagai strate- 
gi antara lain diskusi, penugasan individual dan kelompok. Pelaksanaan pembelajaran dengan bantuan CD pembelajaran, video, slide powerpoint, artikel dari berbagai media cetak dan internet. Penilaian akhir dengan bobot terbesar 30\% dari penugasan.

Paradigma utama proses pembelajaran adalah bagaimana membelajarkan mahasiswa. Setelah pembelajaran, mahasiswa harus dapat menerapkan apa yang telah dipelajari, untuk memecahkan masalah yang dihadapinya dalam kehidupan sehari-hari. Mahasiswa tidak hanya dipandang sebagai subjek penerima informasi, mendengar dan menghafal, melainkan mahasiswa harus diberikan kesempatan agar lebih aktif dalam menggali serta mengkonstruksi pengetahuan. Setiap mahasiswa yang belajar di Prodi Pendidikan IPA FMIPA Unnes diharapkan mempunyai kompetensi mampu menguasai materi pembelajaran, mampu merancang dan melakukan penelitian, serta melakukan komunikasi ilmiah dengan baik secara lisan maupun tertulis. Kompetensi semacam ini tergambar dalam profil lulusan yang bersifat terbuka, cerdas, terampil, dan tanggap terhadap perubahan dan kemajuan IPA serta permasalahan yang dihadapi masyarakat.

Dalam merancang materi pembelajaran, terdapat lima kategori kapabilitas yang dapat dipelajari oleh peserta didik, yaitu informasi verbal, keterampilan intelektual, strategi kognitif, sikap, dan keterampilan motorik. Kelima hal tersebut untuk selanjutnya dapat dikaji kelemahan dan kekuatan di dalam setiap pelaksanaan pembelajaran sehingga akan diperoleh analisis kasus pembelajaran yang baik (Saito, 2010). Strategi pengorganisasian materi pembelajaran terdiri dari tiga tahapan proses berpikir, yaitu pembentukan konsep, interpretasi konsep, dan aplikasi prinsip. Strategi-strategi tersebut memegang peranan sangat penting dalam mendesain pembelajaran. Kegunaannya dapat membuat lebih tertarik dalam belajar, belajar bertolak dari prerequisites, dan menuntut peran aktif. Kegiatan belajar menemukan yang terlatih dan fokus dapat memberikan dampak nyata sebagai bentuk belajar aktif berbuat (Nugent, 2008).

Melakukan kajian kritis terhadap pelaksanaan pembelajaran dapat mendukung kemampuan seorang guru dalam mengidentifikasi masalah untuk Penelitian Tindakan Kelas (PTK). Dalam pelak- 
sanaannya, guru secara kolaborasi melakukan analisis tahapan pembelajaran yang dilakukan penelitian. Dari kegiatan tersebut, teridentifikasi berbagai permasalahan pembelajaran yang oleh guru observer dijadikan sebagai permasalahan dalam penelitian. Kajian kritis dapat menentukan kualitas kajian teori yang dikembangkan oleh guru sebagai peneliti.

Artikel yang dimuat di berbagai jurnal telah melalui serangkaian proses seleksi sebelum terbit sehingga secara kualitas tidak diragukan lagi. Berdasarkan hasil penelitian bahwa dalam pembelajaran strategi belajar mengajar melalui pemanfaatan hasil-hasil penelitian pembelajaran IPA di sekolah yang telah dipublikasikan di jurnal sangat baik dijadikan sebagai bahan untuk mengembangkan bahan ajar yang akan digunakan oleh mahasiswa dalam pembelajaran (Parmin, 2011).

Proses pembelajaran IPA dapat memperoleh hasil belajar yang baik jika isi dan prosedur pembelajaran diorganisasi menjadi urutan yang bermakna, bahan disajikan dalam bagian-bagian yang bergantung pada kedalaman dan kesulitannya (Kabba, 2009). Untuk tujuan tersebut diperlukan langkah sintesis pembelajaran. Mensintesis adalah mengaitkan topik-topik suatu bidang studi dengan keseluruhan isi bidang studi, sehingga isi yang disajikan lebih bermakna menyebabkan mahasiswa memiliki ingatan yang baik dan lebih tahan lama terhadap topik-topik yang dipelajari.

Hasil penelitian Suhartawan (2004) untuk mengoptimalkan keterampilan proses IPA dalam pembelajaran dapat dilakukan dengan mengkaji data dan fakta dari suatu objek kajian. Kegiatan tersebut apabila dirancang dengan terstruktur dan berkelanjutan dapat menghasilkan peneliti yang kritis. Menurut Heron (1997) bahwa sains merupakan kumpulan pengetahuan yang diperoleh dengan menggunakan metode-metode berdasarkan observasi. Dengan demikian pembelajaran sains diharapkan ada kerterlibatan langsung antara peserta belajar dengan obyek yang sedang dipelajarinya karena pembelajaran sains akan menemukan pengertian-pengertian tentang sejumlah gejala melalui pengetahuan hasil kajian terhadap suatu sumber atau objek. Dari hasil penelitian tentang kompetensi mahasiswa dalam merencanakan penelitian ilmiah menunjukkan 
bahwa nilai rerata persentase kompetensi melakukan penelitian $67 \%$, terdapat dua hal yang perlu dioptimalkan yaitu kemampuan menentukan langkah kerja dan menentukan cara menganalisis data.

Kajian kritis yang akan dilakukan mahasiswa untuk berlatih menganalisis sumber belajar dalam rangka menemukan kebaikan dan kelemahan, tanpa melakukan perubahan terhadap artikel jurnal yang dikaji. Dalam rangka memberikan bekal pada mahasiswa agar dapat menyusun rencana penelitian maka kajian kritis sangat diperlukan. Kegiatan akan diawali dengan menentukan artikel jurnal yang sesuai untuk dianalisis, membaca, menelaah artikel untuk memperoleh ide-ide pengembangan, penjelasan, dan memberikan komentar terhadap isi bacaan secara keseluruhan dari sudut pandang kepentingan mahasiswa sebagai pengkaji.

\section{METODE}

Penelitian dirancang dengan metode penelitian tindakan kelas yang direncanakan secara khusus untuk mengatasi permasalahan belajar mahasiswa, karena kesulitan menyusun proposal penelitian skripsi melalui proses pembelajaran mata kuliah Metodologi Penelitian. Penelitian tindakan kelas, akan dilaksanakan selama 2 siklus dengan masing-masing siklus terdiri dari 4 tahapan yaitu; perencanaan, pelaksanaan, observasi, dan refleksi (Susilo, 2009). Tahapan masing-masing siklus yang akan ditempuh sebagai berikut.

Langkah-langkah yang akan dilakukan dalam perencanaan; a) mengkaji prosedur penyusunan perangkat pembelajaran dengan penekanan pada kegiatan kajian kritis artikel jurnal; b) menyusun perangkat pembelajaran yang terdiri dari; kontrak perkuliahan, satuan acara perkuliahan dan sumber/media pembelajaran; c) merancang panduan kajian kritis yang akan digunakan mahasiswa dalam melakukan kajian terhadap artikel jurnal penelitian pendidikan IPA di sekolah; d) menyusun instrumen penilaian proposal mahasiswa untuk menilai layak atau tidak dilanjutkan ke skripsi; dan e) menentukan observer yang akan diminta untuk mengumpulkan data dan fakta dalam pelaksanaan pembelajaran.

Pelaksanaan tindakan dalam proses pembelajaran akan dilakukan sebanyak 2 siklus. Masing-masing siklus terdiri dari dua 
kali pertemuan. Bentuk kegiatan pembelajaran, mahasiswa dengan bimbingan dosen akan menentukan artikel jurnal yang akan dikaji, dan menyusun laporan kajian kritis yang dihasilkan, masing-masing siklus ditempuh dalam 2 kali pertemuan atau kegiatan critical review terhadap artikel jurnal tentang pembelajaran IPA di sekolah.

Tahapan pelaksanaan pembelajaran meliputi: a) disajikan contoh hasil kajian kritis dari suatu artikel jurnal tentang penelitian pelaksanaan pembelajaran IPA di sekolah; b) mahasiswa secara individu berlatih menelusuri, menentukan dan mengkaji satu artikel setiap pertemuan pembelajaran; c) melakukan critical review artikel jurnal pembelajaran IPA; d) melaporkan sesuai sistematika kajian kritis pada panduan; dan e) menindaklanjuti dalam penyusunan proposal skripsi sebagai penugasan akhir mata kuliah metodologi penelitian. Proses mengobservasi untuk mengumpulkan data penelitian yang dilakukan pada saat pembelajaran. Kegiatan mengobservasi dilakukan oleh tiga orang observer, untuk mengumpulkan data yang terdiri dari: a) proses critical review artikel jurnal pembelajaran IPA di sekolah yang dilakukan secara individu oleh mahasiswa, b) penilaian produk laporan kajian kritis, c) penilaian proposal skripsi sebagai tugas akhir di mata kuliah metodologi penelitian, dan d) penilaian kinerja dosen dalam pelaksanaan pembelajaran.

Kegiatan yang akan dilakukan meliputi; a) menganalisis temuan saat melakukan observasi pelaksanaan pembelajaran; b) menganalisis kelemahan dan keberhasilan mahasiswa saat proses critical review artikel jurnal pembelajaran IPA di sekolah; c) melakukan refleksi terhadap penilaian laporan kajian kritis dan proposal penelitian skripsi mahasiswa; dan d) melakukan refleksi terhadap ketercapaian tujuan penelitian.

\section{HASIL DAN PEMBAHASAN}

Data penelitian yang dikumpulkan pada siklus 1 terdiri dari: keaktifan mahasiswa selama melakukan critical review artikel ilmiah, dan nilai laporan critical review. Selengkapnya hasil penelitian yang telah diperoleh pada siklus 1 disajikan berikut ini.

Hasil observasi terhadap keaktifan belajar mahasiswa disajikan pada Tabel 1. 
Tabel 1.

Rekap Keaktifan Belajar Mahasiswa selama Melakukan Critical Review Artikel Ilmiah Siklus 1

\begin{tabular}{|l|c|c|c|c|}
\hline \multirow{2}{*}{ Tingkat Keaktifan } & \multicolumn{5}{|c|}{$\begin{array}{c}\text { Aspek yang diamati } \\
\text { (Jumlah Mahasiswa) }\end{array}$} \\
\cline { 2 - 5 } & $\mathbf{1}$ & $\mathbf{2}$ & $\mathbf{3}$ & $\mathbf{4}$ \\
\hline Sangat Aktif & 48 & 39 & 48 & 2 \\
\hline Aktif & - & 9 & - & 16 \\
\hline Kurang Aktif & - & - & - & 30 \\
\hline Tidak Aktif & - & - & - & - \\
\hline
\end{tabular}

(1 = membaca, 2 = mencatat, 3 = menyusun hasil kajian, 4 = mengajukan pertanyaan/jawaban)

Mahasiswa sebanyak 48 orang secara individu mengumpulkan laporan kajian kritis artikel ilmiah, selanjutnya dinilai dengan rentang 0 sampai dengan 100. Nilai laporan kajian kritis siklus 1 disajikan pada Diagram 1.

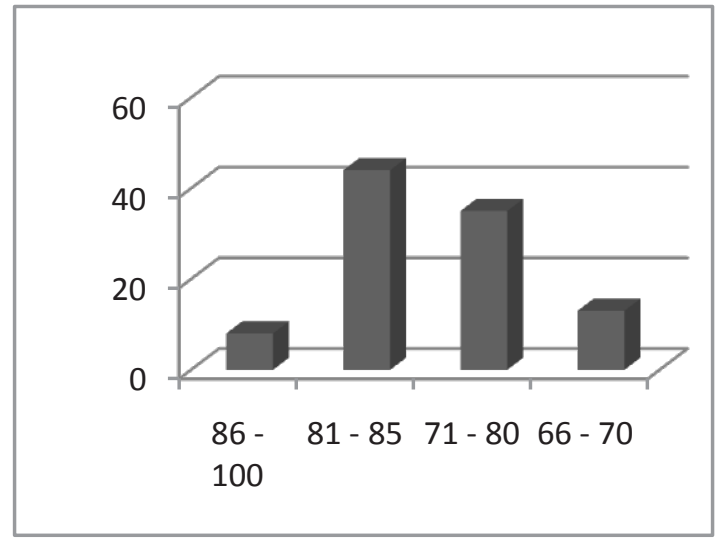

Diagram 1. Nilai Laporan Critical Review Artikel Ilmiah Siklus 1

Selain data keaktifan mahasiswa, dan nilai laporan critical review, pada siklus ke dua juga diperoleh nilai proposal skripsi dan sikap mahasiswa. Hasil observasi terhadap keaktifan belajar mahasiswa disajikan pada Tabel 2. 


\section{Parmin}

Tabel 2.

Rekap Keaktifan Belajar Mahasiswa selama Melakukan Critical Review Artikel Ilmiah Siklus 2

\begin{tabular}{|c|c|c|c|c|}
\hline \multirow{2}{*}{$\begin{array}{c}\text { Tingkat } \\
\text { Keaktifan }\end{array}$} & \multicolumn{4}{|c|}{ Aspek yang diamati } \\
\cline { 2 - 5 } & 1 & 2 & 3 & 4 \\
\hline Sangat Aktif & 48 & 42 & 48 & 6 \\
\hline Aktif & - & 6 & - & 10 \\
\hline Kurang Aktif & - & - & - & 30 \\
\hline Tidak Aktif & - & - & - & - \\
\hline
\end{tabular}

$(1=$ membaca, 2 = mencatat, 3 = menyusun hasil kajian, $4=$ mengajukan pertanyaan/jawaban)

Nilai laporan kajian kritis siklus kedua disajikan pada Diagram 2.

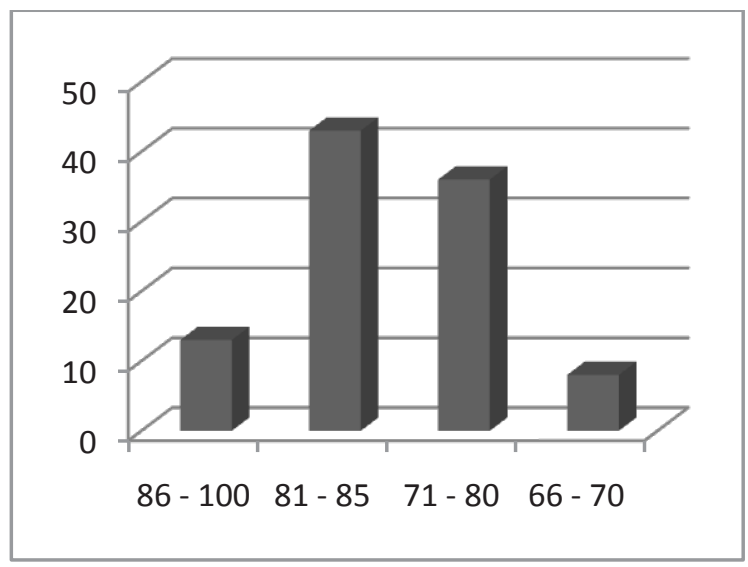

\section{Diagram 2.}

Nilai Laporan Critical Review Artikel Ilmiah Siklus 2

Pada siklus 2 diperoleh nilai proposal penelitian yang diharapkan dapat ditindaklanjuti menjadi proposal skripsi oleh mahasiswa. Nilai proposal yang telah disusun mahasiswa disajikan pada Tabel 3. 
Tabel 3.

Rekap Nilai Proposal Mahasiswa yang disusun setelah Melakukan Critical Review Artikel Ilmiah

\begin{tabular}{|c|c|}
\hline Rentang Nilai & Jumlah Mahasiswa \\
\hline $86-100$ & 2 \\
\hline $81-85$ & 28 \\
\hline $71-80$ & 7 \\
\hline $66-70$ & 11 \\
\hline Jumlah & 48 \\
\hline
\end{tabular}

Dalam rangka mengetahui sikap mahasiswa setelah pelaksanaan pembelajaran pada mata kuliah Metodologi Penelitian menerapkan kegiatan kajian kritis artikel ilmiah, setiap mahasiswa mengisi angket. Data angket mahasiswa disajikan pada Tabel 4.

\section{Tabel 4.}

Sikap Mahasiswa Setelah Pembelajaran Menerapkan

Kajian Kritis Artikel Ilmiah

\begin{tabular}{|l|c|c|}
\hline \multirow{2}{*}{ Pernyataan } & \multicolumn{2}{|c|}{ Jumlah Mahasiswa } \\
\cline { 2 - 3 } & Sangat Setuju & Setuju \\
\hline $\begin{array}{l}\text { Artikel dari jurnal tentang penelitian } \\
\text { pendidikan IPA di sekolah penting seb- } \\
\text { agai sumber belajar }\end{array}$ & 41 & 7 \\
\hline $\begin{array}{l}\text { Setelah mengkaji artikel menjadi lebih } \\
\text { memahami permasalahan pembelajaran } \\
\text { IPA di sekolah }\end{array}$ & 38 & 5 \\
\hline $\begin{array}{l}\text { Pengalaman nyata mengkaji artikel } \\
\text { mempermudah dalam menyusun pro- } \\
\text { posal skripsi }\end{array}$ & 30 & 13 \\
\hline $\begin{array}{l}\text { Mata kuliah metodologi penelitian men- } \\
\text { jadi lebih menarik setelah mengkaji ar- } \\
\text { tikel }\end{array}$ & 39 & 6 \\
\hline
\end{tabular}

Permasalahan yang diatasi melalui penelitian ini berdasarkan hasil refleksi pelaksanaan pembelajaran mata kuliah Metodologi Penelitian di Program Studi Pendidikan IPA Universitas Negeri Semarang bahwa mahasiswa dalam menyusun proposal penelitian sebagai tugas akhir mata kuliah tersebut belum sesuai harapan, mis- 
alnya; judul skripsi pada penelitian tindakan kelas sebagian besar bukan hasil identifikasi permasalahan pembelajaran di sekolah, melainkan hasil membaca skripsi pendahulu, kajian pustaka yang digunakan belum faktual karena tidak bersumber dari rujukan yang terbaru, dan minim menggunakan rujukan artikel yang bersumber dari jurnal sedangkan mahasiswa mulai angkatan 2009 dituntut untuk menyusun artikel hasil penelitian yang akan dipublikasi melalui jurnal sebagai syarat lulus. Oleh karena itu, dalam penelitian ini mahasiswa diberi latihan untuk mengkaji artikel hasil penelitian sehingga diharapkan mampu menyusun rencana penelitian dalam bentuk proposal skripsi sekaligus terlatih menyusun artikel jurnal.

Artikel yang dikaji mahasiswa berkaitan dibatasi seputar permasalahan belajar IPA di sekolah. Hasil kajian dimanfaatkan oleh mahasiswa sebagai bahan diskusi kelas untuk mempelajari berbagai metode yang telah digunakan untuk mengatasi permasalahan belajar IPA. Kegiatan diawali dengan memilih artikel karena jumlah artikel yang telah disiapkan setiap mahasiswa paling sedikit tiga artikel sehingga dilakukan pemilihan. Sebagai dasar penentuan artikel yang dipilih dilakukan sesuai ketertarikan mahasiswa terhadap permasalahan yang diteliti.

Berdasarkan pengamatan selama pemilihan artikel, sebagian besar mahasiswa telah mampu menentukan artikel dengan tepat, kriteria ini ditentukan dari kesesuaian dengan bidang kajian, faktual dan bersumber dari jurnal yang ber ISSN yang on line maupun cetak. Keadaan ini menunjukkan bahwa mahasiswa apabila diberi kesempatan dan kepercayaan untuk menelusuri sumber belajar dalam bentuk artikel ternyata mampu mendapatkan artikel yang tepat sesuai bidang studinya. Pemberian motivasi yang merangsang keingintahuan mahasiswa agar dapat memilih tema skripsi yang faktual terbukti mampu memicu aktivitas membaca, mencatat, dan menyusun hasil kajian sesuai sistematika yang telah ditetapkan.

Antusiasme mahasiswa ketika melakukan kajian artikel untuk mendapatkan pengetahuan tentang cara mengatasi masalah belajar siswa pada siklus satu memang masih terdapat, karena sebagian besar masih belum mampu memberikan ide atau gagasan ketika pembahasan melalui diskusi kelas. Setelah dilakukan refleksi den- 
gan observer, diperoleh informasi bahwa mahasiswa sebagian besar sibuk dengan aktivitas membaca dan menyusun hasil kajian artikelnya secara individu, dan belum diberi kesempatan yang lebih banyak lagi untuk melakukan sharing informasi hasil kajian yang telah disusunnya.

Produk yang dihasilkan dari kegiatan kajian artikel yaitu laporan critical review yang disusun oleh mahasiswa secara individu. Berdasarkan penilaian laporan, untuk siklus satu sebanyak 52\% mahasiswa telah mendapatkan nilai di atas 80. Kemampuan mahasiswa secara umum masuk kategori baik dari indikator nilai akhir, namun demikian pada bagian laporan untuk komponen argumentasi, masih ditemukan kelemahan dalam penyajian alasan yang tepat mengapa penulis artikel yang artikelnya dikaji memilih masalah tersebut yang diatasi. Bagian ini mestinya mahasiswa juga diharapkan dapat memberikan pendapat bentuk penelitian lanjutan yang dapat dilakukan dari fakta dan data yang disajikan. Dari analisis bagian argumentasi masih diperlukan penjelasan kepada mahasiswa dengan diberikan contoh bentuk narasi argumentasi yang baik.

Komponen laporan yang juga masih perlu perbaikan yaitu tentang pernyataan umum mengenai penilaian terhadap artikel yang dikaji. Kelemahan ada pada keseimbangan antara penilaian terhadap kelebihan dan kelemahan dari artikel. Selain itu, ditemukan juga sebagian besar mahasiswa menilai kelebihan artikel tanpa ada kelemahannya atau sebaliknya. Permasalahan ini muncul karena masih lemahnya pemahaman teori yang dimiliki mahasiswa terkait tema dalam artikel.

Berbagai kelemahan pada siklus satu, dijadikan bahan perbaikan dalam penelitian ini agar tujuan penelitian dapat tercapai. Beberapa kegiatan untuk perbaikan siklus kedua yang dilakukan meliputi;1) kegiatan mengkaji artikel tidak dilakukan langsung di kelas saat pembelajaran, melainkan telah dilakukan sebagai penugasan rumah dengan memperhatikan pengalaman siklus satu, mengingat waktu yang sangat terbatas dengan tagihan yang harus dikumpulkan oleh mahasiswa; 2) diskusi antar mahasiswa berdasarkan pengalaman mengkaji artikel difokuskan pada penentuan tema penelitian lanjutan yang dapat dipertimbangkan mahasiswa setelah 
mempelajari penulisan proposal penelitian; 3) menyajikan penjelasan tentang bentuk argumentasi yang didasarkan pada fakta/data di artikel sehingga mahasiswa dapat menilai kelemahan dan keunggulan artikel lebih berimbang dengan dukungan data sebagai bentuk pembelajaran; dan 4) mahasiswa diminta untuk membaca referensi tambahan terkait variabel yang terdapat dalam setiap artikel dari buku dan sumber bacaan lainnya agar lebih menguasai konsep kajian teori pada setiap variabel dalam artikel.

Capaian siklus kedua ternyata lebih dapat dioptimalkan dengan usaha perbaikan yang telah ditetapkan melalui kegiatan sharing dengan observer. Peran aktif mahasiswa menjadi lebih baik, dikarenakan pengalaman siklus satu telah dijadikan pelajaran berharga sebagai bahan perbaikan siklus kedua. Kegiatan mengkaji artikel yang dijadikan bentuk penugasan rumah dapat mengefisiensikan waktu diskusi di kelas sehingga terlihat jumlah mahasiswa yang berani mengajukan ide atau gagasan dari artikel yang dikaji untuk menentukan tema-tema skripsi terlihat lebih banyak.

Dampak dari suatu kegiatan membaca, menelaah, menganalisis bacaan/artikel dapat membantu mahasiswa mendapatkan ideide dan mendukung argumentasi untuk memberikan komentar terhadap isi bacaan secara keseluruhan dari sudut pandang kepentingan pengkaji. Kemampuan melakukan kajian kritis sangat diperlukan oleh mahasiswa sebagai bagian dari latihan nyata menyusun rencana penelitian sekaligus menyusun artikel hasil penelitian yang layak publikasi di jurnal. Kemampuan melakukan kajian kritis, dapat digunakan untuk membuat rencana perbaikan pembelajaran IPA di sekolah. Menurut Volante (2007) kegiatan asesmen yang berorientasi untuk pengembangan (assessment for learning) lebih dibutuhkan guna meningkatkan kualitas pembelajaran. Bentuknya dapat mengkaji suatu sumber belajar kemudian mengembangkan produk dari kegiatan yang telah dilakukan.

Fakta dan data penelitian di setiap artikel yang telah dikaji, oleh sebagian mahasiswa telah ditentukan sebagai dasar pemberian argumen kelebihan dan keunggulan artikel. Terdapat argumen yang menyatakan bahwa penjelasan pada pembahasan telah sesuai dengan data dan fakta penelitian, dan pola sajian yang runtun, oleh 
mahasiswa dianggap mudah dipahami karena konsistensi penjelasan data didukung temuan selama penelitian. Berdasarkan perbaikan pada kemampuan mahasiswa menyusun argumentasi kajian artikel, dapat mempengaruhi penilaian laporan critical review atau kajian kritis, karena pada siklus kedua lebih banyak lagi mahasiswa yang mendapatkan nilai diatas 80. Peningkatan nilai tentu tidak terlepas dari usaha perbaikan yang telah dilakukan secara kolaborasi dalam penelitian ini.

Membaca referensi terkait variabel-variabel yang terdapat pada artikel yang dikaji telah mampu memberikan tambahan informasi sehingga berdampak pada tingkat pemahaman mahasiswa tentang berbagai kajian teori yang mendukung sebuah tujuan penelitian. Pengalaman ini tentu sangat berharga, mengingat mahasiswa dapat berlatih memilih sumber rujukan yang sesuai dengan tema proposal skripsi yang akan disusun. Bahkan, ada mahasiswa yang kemudian menyampaikan bahwa tidak mungkin seorang peneliti mengerti tingkat keberhasilan penelitiannya apabila aspek yang diteliti tidak dikaji melalui membaca rujukan yang tepat yaitu artikel di jurnal.

Produk akhir untuk mata kuliah Metodologi Penelitian sesuai silabus yaitu proposal skripsi yang disusun secara individu. Berdasarkan penilaian proposal skripsi diperoleh hasil bahwa 30 orang mahasiswa dari 48 telah mampu menyusun proposal skripsi dengan baik karena mendapatkan nilai diatas 80 . Kemampuan mahasiswa dalam penyusunan proposal skripsi sebagai dampak nyata pengalaman mahasiswa melakukan kajian kritis artikel ilmiah. Selain sistematika proposal yang telah sesuai, judul-judul skripsi juga menunjukkan kualitas yang baik. Fakta sebelum penelitian menunjukkan bahwa proposal yang dibuat sebagian besar tidak layak dilanjutkan untuk skripsi sehingga secara umum tujuan mata kuliah agar mahasiswa dapat menyusun proposal penelitian yang mendapat penilaian layak untuk proposal skripsi belum tercapai. Berdasarkan fakta-fakta dan dukungan data hasil belajar mahasiswa melalui penelitian ini, permasalahan tersebut telah dapat diatasi.

Untuk mengetahui secara pasti dampak langsung dari kegiatan kajian kritis artikel ilmiah terhadap kemampuan mahasiswa menyusun proposal skripsi. Kegiatan akhir penelitian dilakukan dengan 
pengumpulan data sikap mahasiswa melalui angket. Sebagian besar mahasiswa menilai bahwa artikel penting sebagai sumber belajar pada mata kuliah Metodologi Penelitian karena dapat memberikan pengalaman nyata tentang suatu penelitian. Setelah mengkaji artikel menjadi lebih memahami kompleksitas permasalahan belajar IPA di sekolah yang dapat dijadikan bahan penentuan tema skripsi.

Mahasiswa juga berpendapat bahwa melalui kegiatan melakukan kajian artikel ilmiah, pembelajaran menjadi lebih bermakna mengingat penyusunan proposal skripsi pasti dibutuhkan oleh setiap mahasiswa. Menurut Widyatiningtyas (2009) bahwa pembentukan pengetahuan bagi seseorang yang sedang belajar IPA dapat dilakukan dengan mengembangkan rasa ingin tahu melalui sesuatu kegiatan yang bermakna.

Selain itu, dengan kewajiban mahasiswa menyusun artikel dari penelitiannya, setelah memiliki pengalaman menganalisis suatu artikel hasil penelitian nantinya diharapkan dapat menjadi bekal keterampilan menyusun artikel skripsi.

\section{PENUTUP}

Berdasarkan hasil yang telah diperoleh dalam penelitian ini maka dapat disimpulkan; penerapan critical review atau kajian kritis terhadap artikel ilmiah dapat meningkatkan kemampuan mahasiswa dalam menyusun proposal penelitian.

Saran yang dapat diberikan, demi perbaikan penelitian yang berupaya mengatasi permasalahan kemampuan mahasiswa dalam menyusun skripsi yaitu; a) sebelum menyusun proposal skripsi, mahasiswa membutuhkan latihan dalam pembelajaran yaitu melalui kegiatan mengkaji artikel ilmiah, selain dapat memberikan pengalaman nyata sekaligus mahasiswa akan memiliki budaya menghargai karya pendahulu; b) apabila ingin memberikan pengalaman dalam bentuk mengkaji artikel ilmiah bagi mahasiswa, perlu diawali dengan dorongan kuat tentang manfaat dari kegiatan tersebut, mengingat tingkat kebutuhan yang tinggi dalam belajar dapat menciptakan kemandirian belajar. 


\section{DAFTAR PUSTAKA}

Heron, S.D., 1997. Problem Associated with Concept Analysis. Journal of Science Education. 6 (2) 185-199.

Heriawan Iwan, dkk. 2009. Panduan Kajian Kritis Program Bermutu. Kemendiknas: P4TK IPA Bandung.

Kabba E. Colley. 2009. Based Science Instruction: Teaching Science for Understanding. Journal of Research in Science Teaching. Vol. 39, No. 5, pp. (410-422).

Nugent, G; Kunz, G; Levy, R and David Harwood; Carlson, D. 2008. The Impact of a Field-Based, Inquiry-Focused Model of Instruction on Preservice Teachers' Science Learning and Attitudes. Electronic Journal of Science Education. Vol. 12, No. 2.

Parmin dan Endah P. 2011. Pengembangan Modul Mata Kuliah Strategi Belajar Mengajar IPA Berbasis Hasil Penelitian Pembelajaran. Jurnal Pendidikan IPA Indonesia. Volume 1 (1), (4356).

Suhartawan, B., dkk. 2004. Mengoptimalkan Pendekatan Keterampilan Proses IPA dalam Pembelajaran di Laboratorium. Jurnal Pendidikan dan Pengajaran. Vol. 2 No. 2.

Susilo, H., Husnul C, dan Yuyun D. 2009. Penelitian Tindakan Kelas. Surabaya: Bayumedia Publishing.

Sopiah, dkk. 2009. Pembiasaan Bekerja Ilmiah pada Pembelajaran Fisika. Jurnal Pendidikan Fisika. Volume 5 (20-27). 
Parmin

Saito, dkk. 2010. Case Study of Indonesian Mathematics and Science Teacher. Journal of In-service Education. 32 (2): (171-184).

Volante, L \& Fazio, X. 2007. Exploring Teacher Candidates' Assessment Literacy: Implications for Teacher Education Reform and Professional Development. Can. Jou. of Edu. 30, 3 : 749-770.

Widyatiningtyas, R. 2009. Pembentukan Pengetahuan Sains, Teknologi dan Masyarakat dalam Pandangan Pendidikan IPA. EDUCARE: Jurnal Pendidikan dan Budaya. http://educare.efkipunla.net. Diakses 12 Januari 2014. 